\title{
Partial replacement of DL-Methionine and methionine hydroxy analogue with betaine in diets for broiler chickens
}

\author{
L. Silva1, B.S. Vieira ${ }^{2}$, L.D. Castilha ${ }^{3}$, S.E. Takahashi ${ }^{1}$, A.S. Avila ${ }^{4}$, \\ C. Souza ${ }^{4}$, P.S. Cella ${ }^{1}$, J. Broch ${ }^{4}$ \& R.V. Nunes ${ }^{4}$ \\ ${ }^{1}$ Federal University of Technology - Paraná, Dois Vizinhos, PR, Brazil \\ ${ }^{2}$ Federal Institute of Education Science and Technology of Mato Grosso, Alta Floresta, MT, Brazil \\ ${ }^{3}$ Maringá State University, Maringá, PR, Brazil \\ ${ }^{4}$ Western Paraná State University, Marechal Cândido Rondon, PR, Brazil
}

(Received 6 October 2020; Accepted 23 June 2021; Published 27 August 2021)

\begin{abstract}
Copyright resides with the authors in terms of the Creative Commons Attribution 4.0 South African Licence.
See: http://creativecommons.org/licenses/by/4.0/za

Condition of use: The user may copy, distribute, transmit and adapt the work, but must recognise the authors and the South African Journal of Animal Science.
\end{abstract}

\begin{abstract}
The study evaluated the effects on the growth performance and carcass characteristics of broiler chickens of DL-Methionine (DL-Met) and methionine hydroxy analogue (MHA) supplementation and their partial replacement with betaine (Bet). Two experiments were performed from day 1 to 21 and from day 22 to 42. Broiler chickens were assigned to six treatments, in a completely randomized design and a $2 \times 2+2$ factorial arrangement, consisting of two Met sources (DL-Met and MHA), with or without Bet, and two negative controls. The six treatments consisted of i) NC-DLM: negative control for DL-Met with $7 \%$ reduction in DL-Met; ii) NC-MHA: negative control for MHA with 7\% reduction of MHA, iii) $\mathrm{DLM}_{100}$ : without Bet, supplemented exclusively with DL-Met reaching $100 \%$ of requirements, iv) $\mathrm{MHA}_{100}$ : without Bet supplemented exclusively with MHA reaching $100 \%$ of requirements, v) $\mathrm{DLM}_{93}+$ Bet: DL-Met at $93 \%$ of recommended level plus betaine; vi) $\mathrm{MHA}_{93}+\mathrm{Bet}$ : $\mathrm{MHA}$ at $93 \%$ of recommended level plus betaine. Growth from day 1 to 21 was not altered by methionine source or betaine supplementation. However, the negative controls had numerically less weight gain and feed conversion ratio (FCR). Between days and 42 there were no effects on growth. Betaine could partially replace methionine without altering the growth of broiler chickens. In addition, the partial replacement of DL-Met with betaine increased body crude protein content. However, its use increased body fat content regardless of methionine source.
\end{abstract}

Keywords: amino acid, carcass composition, growth, methyl source

"Corresponding author: sanches989@hotmail.com

\section{Introduction}

Methionine is one of the more limiting amino acids in animal nutrition, with an important function in protein synthesis. It is also a source of methyl groups, which are important in metabolism and must be supplied in the diets as they cannot be synthesized (Sun et al., 2008; Nutautaite et al., 2020). The usual supplemental sources of methionine are DL-Met and MHA (Payne et al., 2006), which is chemically different from DL-Met because it has a hydroxyl group at the asymmetric carbon atom, whereas DL-Met has an amino group. This chemical difference lowers the bioavailability of MHA compared with DL-Met (Rehman et al., 2019; Sauer et al., 2008).

The methyl groups found in betaine may provide benefits by sparing methionine as a methyl donor and permitting methionine to be directed towards protein synthesis (Sun et al., 2008; Nutautaitë et al., 2020). Betaine is a natural compound that is synthesized by a variety of plants and organisms and is important for synthesis of methionine and carnitine (Shakeri et al., 2019). On a molecular weight basis, betaine contains about 3.75 times more methyl groups than methionine, and have been shown to counteract the partial deficiency of labile methyl groups in corn-soybean-based diets (Rama Rao et al., 2011; Sun et al., 2008).

Betaine also acts in lipid metabolism, being associated with enhanced synthesis of methylated compounds such as carnitine and creatine in the liver and muscle. By increasing the concentration of 
carnitine in the liver, it can facilitate fatty acid oxidation and reduce the amount of long-chain fatty acids to be stored in adipose tissue (Chen et al., 2018), thus altering carcass characteristics (Leng et al., 2016).

Reported effects of betaine on broiler chicken carcasses are conflicting (Fu et al., 2016). Some studies observed lower fat deposition in broilers supplemented with betaine (He et al., 2015; Leng et al., 2016). However, others reported increased fat accumulation (Garcia Neto et al., 2000; Zhan et al., 2006). According to Sun et al. (2008), Bet and methionine in marginally methionine-deficient diets could lead to an equivalent growth response in broiler chickens, and Bet could spare a small portion of the methionine. However, the effect of Bet supplementation on feed efficiency may depend on diet composition, dietary level of methionine and level of Bet supplementation, breed, and rearing environment (Sun et al., 2008; Chen et al., 2018).

Thus, partial replacement of methionine sources with betaine was hypothesized to alter body composition while maintaining the growth rate of broiler chickens. It was further hypothesized that this effect depended on the methionine source. Thus, the aim of this study was to evaluate the effects of betaine supplementation in diets with reduced DL-Met or MHA for effects on growth, carcass traits and body composition of broiler chickens at various ages.

\section{Materials and methods}

This study was performed at the poultry research centre of Western Paraná State University, Unioeste, Marechal Cândido Rondon, PR, Brazil. All the experimental procedures followed the rules established by the National Council for the Control of Animal Experimentation in Brazil and had been approved by the Animal Use Ethics Committee of the university, under number 25/2014.

Two trials were initiated using one-day-old male broiler chickens (Cobb 500) obtained from a commercial hatchery. In both trials, birds were placed in the same curtain-sided house and raised in pens measuring $1.76 \mathrm{~m}^{2}$ with concrete floors that were covered with wood shavings. The pens were equipped with tubular feeders and nipple drinkers, and the chickens received feed and water ad libitum. For trial 1, 660 one-day-old broiler chickens were weighed individually (mean weight $=45.38 \pm 0.57 \mathrm{~g}$ ) and assigned to a completely randomized design in a $2 \times 2+2$ factorial arrangement with five replicates (pens) of 22 broiler chickens. The treatments consisted of two methionine sources, two betaine supplementation levels (with or without Bet), and two negative controls (reduced for DL-methionine or MHA). The diets consisted of i) NCDLM: a negative control with $7 \%$ less DL-Met, ii) NC-MHA: a negative control with $7 \%$ less MHA, iii) DLM ${ }_{100}$ : a DL-Met supplemented diet, iv) $\mathrm{MHA}_{100}$ : a MHA supplemented diet, and v) diet 1 supplemented with betaine; and vi) diet 2 supplemented with betaine. Both DL-Met and MHA were included based on their equimolar equivalence of 1.125 (Visentini et al., 2005). Betaine hydrochloride 95\% (Btech, Valinhos, SP, Brazil) was used at $0.5 \mathrm{~g} / \mathrm{kg}$ of diet. All the necessary adjustments when changing the level of dietary inclusion of DL-Met, MHA, and/or betaine were made at the expense of corn. These corn and soybean mealbased diets (Table 1) were formulated to meet or exceed the requirements proposed by Rostagno et al. (2011), except for the negative control diets. The chicks were fed these diets until they reached 21 days old when the birds and feeders were weighed to calculate the average feed intake, body weight gain (BWG) and feed conversion ratio (FCR). Mortality was recorded daily and used to correct FCR according to Sakomura \& Rostagno (2016).

In trial 2, 480 one-day-old broiler chickens were raised in similar conditions and fed a common diet until they were 21 days old. Then the birds were weighed individually (mean weight $=729.96 \pm 11.50 \mathrm{~g}$ ) and assigned to a completely randomized design with six treatments and five replications of 16 birds. Treatments were similar to those in trial 1, except for the nutritional composition of the diets, which, following Rostagno et al. (2011), was adjusted to be appropriate to the finishing period (Table 2).

At day 42, the broiler chickens and feeders were weighed and the growth performance was determined. Three birds per pen were selected (pen average weight $\pm 5 \%$ ), fasted for eight hours, weighed and slaughtered. One of these birds was immediately stored at $-20^{\circ} \mathrm{C}$ for further chemical analysis. The two remaining birds were scalded, plucked, and eviscerated. The head, neck, and feet of each were removed and the hot carcass was weighed. The carcasses were assembled as breast, wings, and legs according to commercial practices, weighed, and then analysed as percentages of the hot carcass.

After 30 days, the frozen birds were thawed at room temperature, ground, dried $\left(65^{\circ} \mathrm{C}, 72\right.$ hours), and analysed according to AOAC (1990) for dry matter (DM) (method 93.01), crude protein (CP) (method 981.10), and total fat (method 920.85). 
Table 1 Ingredients and calculated composition ( $\mathrm{g} / \mathrm{kg}$ as-fed) of experimental diets for broiler chickens from day 1 to 21 with different sources of methionine

\begin{tabular}{lrrrrrr}
\hline Ingredient & $\mathrm{DLM}_{100}$ & $\mathrm{NC}^{-\mathrm{DLM}_{93}}$ & $\mathrm{DLM}_{93}+\mathrm{Bet}$ & $\mathrm{MHA}_{100}$ & $\mathrm{NC}^{-\mathrm{MHA}_{93}}$ & $\mathrm{MHA}_{93}+\mathrm{Bet}$ \\
\hline Corn, 78.8 g CP/kg & 574.2 & 574.9 & 574.4 & 573.5 & 574.2 & 573. \\
Soybean meal, 450 g CP/kg & 369.0 & 369.0 & 369.0 & 369.0 & 369.0 & 369.0 \\
Soybean oil & 18.0 & 18.0 & 18.0 & 18.0 & 18.0 & 18.0 \\
Monocalcium phosphate & 14.7 & 14.7 & 14.7 & 14.7 & 14.7 & 14.7 \\
Limestone & 12.0 & 12.0 & 12.0 & 12.0 & 12.0 & 12.0 \\
Salt & 5.3 & 5.3 & 5.3 & 5.3 & 5.3 & 5.3 \\
Premix & 2.2 & 2.2 & 2.2 & 2.2 & 2.2 & 2.2 \\
L-Lysine (78\%) & 1.7 & 1.7 & 1.7 & 1.7 & 1.7 & 1.7 \\
L-Threonine (99\%) & 0.4 & 0.4 & 0.4 & 0.4 & 0.4 & 0.4 \\
DL-Methionine (98\%) & 2.6 & 1.9 & 1.9 & 0.0 & 0.0 & 0.0 \\
Methionine hydroxy analogue & 0.0 & 0.0 & 0.0 & 3.3 & 2.6 & 2.60 \\
Betaine & 0.0 & 0.0 & 0.5 & 0.0 & 0.0 & 0.5 \\
Composition & & & & & & \\
Metabolizable energy, MJ/kg & 12.35 & 12.35 & 12.34 & 12.34 & 12.34 & 12.33 \\
Crude protein, g/kg & 218 & 218 & 217 & 216 & 216 & 216 \\
Digestible lysine, g/kg & 12 & 12 & 12 & 12 & 12 & 12 \\
Digestible methionine + cysteine, g/kg & 8.5 & 7.9 & 7.9 & 8.5 & 7.9 & 7.9 \\
Digestible threonine, g/kg & 7.8 & 7.8 & 7.8 & 7.8 & 7.8 & 7.8 \\
Betaine, g/kg & 0.0 & 0.0 & 0.4 & 0.0 & 0.0 & 0.4 \\
Calcium, g/kg & 8.6 & 8.6 & 8.6 & 8.6 & 8.6 & 8.6 \\
Available phosphorus, g/kg & 4.4 & 4.4 & 4.4 & 4.4 & 4.4 & 4.4 \\
Sodium. g/kg & 2.2 & 2.2 & 2.2 & 2.2 & 2.2 & 2.2 \\
& & & & & &
\end{tabular}

$\mathrm{DLM}_{100}$ : DL-Methionine supplemented, NC-DLM93: negative control supplemented with DL-Met at 93\% of DLM 100 , DLM $_{93}+$ Bet: $\mathrm{DLM}_{93}$ supplemented with Betaine; $\mathrm{MHA}_{100}$ : methionine hydroxy analogue (MHA) supplementation; MHA negative control supplemented with $93 \%$ of $\mathrm{MHA}, \mathrm{MHA}_{93}+\mathrm{Bet}_{\mathrm{MHA}} \mathrm{MH}_{93}$ supplemented with betaine

${ }^{1}$ Vitamin $A: 10,000 \mathrm{IU}$, vitamin $D_{3}: 2,500 \mathrm{IU}$, vitamin $\mathrm{E}: 20,000 \mathrm{UI}$, vitamin $\mathrm{K}_{3}: 2,500 \mathrm{mg}$, vitamin $B_{1}: 1,800 \mathrm{mg}$, vitamin $B_{2}: 6,000 \mathrm{mg}$, vitamin $B_{12}: 16,000 \mathrm{mcg}$, vitamin $B_{6}: 2,600 \mathrm{mg}$, vitamin $B_{3}: 40,000 \mathrm{mg}$, vitamin $B_{5}: 12,000 \mathrm{mg}$, vitamin $B_{7}$ : $65 \mathrm{mg}$, vitamin $\mathrm{B}_{9}: 1,000 \mathrm{mg}$, iron: $50 \mathrm{~g}$, copper: $9 \mathrm{~g}$, zinc: $60 \mathrm{~g}$, manganese: $70 \mathrm{~g}$, iodine: $1 \mathrm{~g}$, selenium: $0.3 \mathrm{~g}$, choline chloride: $0.5 \mathrm{~g}$, salinomycin: $0.55 \mathrm{~g}$, virginiamycin: $0.05 \mathrm{~g}$

For both trials, the data were subjected to analysis of variance and the residuals were evaluated to ascertain the homogeneity of variance among the treatment groups. The treatment means were compared using Tukey's test, with the exception of the negative controls, which were compared with the other treatments with a Dunnett's test. The significance threshold was a probability of 0.05 . All statistical procedures were performed using the general linear model procedure of SAS version 9.1 (SAS Institute Inc., Cary, North Carolina, USA). The model was:

$$
y_{i j k}=\mu+B_{i}+M_{j}+B M_{i j}+e_{i j k}
$$

where: $y_{i j k}=$ observation,

$\mu=$ overall mean,

$B_{i}=$ effect of betaine,

$M_{j}=$ effect of methionine source,

$B M_{i j}=$ effect of interaction between betaine and methionine source, and

$e_{i j k}=$ experimental random residual error. 
Table 2 Ingredients and calculated composition ( $\mathrm{g} / \mathrm{kg}$ as-fed) of experimental diets for broiler chickens from day 22 to 42 with different methionine sources

\begin{tabular}{lrrrrrr}
\hline Ingredient & $\mathrm{DLM}_{100}$ & $\mathrm{NC}^{-\mathrm{DLM}_{93}}$ & $\mathrm{DLM}_{93}+\mathrm{Bet}$ & $\mathrm{MHA}_{100}$ & $\mathrm{NC}^{-\mathrm{MHA}_{93}}$ & $\mathrm{MHA}_{93}+\mathrm{Bet}$ \\
\hline Corn, 78.8 g CP/kg & 583.0 & 583.7 & 583.2 & 582.5 & 583.2 & 582.7 \\
Soybean meal, 450 g CP/kg & 332.5 & 332.5 & 332.5 & 332.5 & 332.5 & 332.5 \\
Soybean oil & 52.9 & 52.9 & 52.9 & 52.9 & 52.9 & 52.9 \\
Monocalcium phosphate & 11.6 & 11.6 & 11.6 & 11.6 & 11.6 & 11.6 \\
Limestone & 10.2 & 10.2 & 10.2 & 10.2 & 10.2 & 10.2 \\
Salt & 4.2 & 4.2 & 4.2 & 4.2 & 4.2 & 4.2 \\
Premix & 2.2 & 2.2 & 2.2 & 2.2 & 2.2 & 2.2 \\
L-Lysine (78\%) & 0.9 & 0.9 & 0.9 & 0.9 & 0.9 & 0.9 \\
L-Threonine (99\%) & 0.3 & 0.3 & 0.3 & 0.3 & 0.3 & 0.3 \\
DL-Methionine (98\%) & 2.2 & 1.5 & 1.5 & 0 & 0 & 0 \\
Methionine hydroxy analogue & 0 & 0 & 0 & 2.7 & 2.0 & 2.0 \\
Betaine & 0 & 0 & 0.5 & 0 & 0 & 0.5 \\
Composition & & & & & & \\
Metabolizable energy, MJ/kg & 13.39 & 13.39 & 13.39 & 13.39 & 13.39 & 13.39 \\
Crude protein, g/kg & 200.7 & 200.4 & 200.4 & 199.4 & 199.4 & 199.4 \\
Digestible lysine, g/kg & 10.5 & 10.5 & 10.5 & 10.5 & 10.5 & 10.5 \\
Digestible methionine + cysteine, g/kg & 7.7 & 7.1 & 7.1 & 7.7 & 7.1 & 7.1 \\
Digestible threonine, g/kg & 7.0 & 7.0 & 7.0 & 7.0 & 7.0 & 7.0 \\
Betaine, g/kg & 0.0 & 0.0 & 0.04 & 0.0 & 0.0 & 0.04 \\
Calcium, g/kg & 7.2 & 7.2 & 7.2 & 7.2 & 7.2 & 7.2 \\
Available phosphorus, g/kg & 3.7 & 3.7 & 3.7 & 3.7 & 3.7 & 3.7 \\
Sodium. g/kg & 1.8 & 1.8 & 1.8 & 1.8 & 1.8 & 1.8 \\
& & & & & &
\end{tabular}

$\mathrm{DLM}_{100}$ : DL-Methionine supplemented, NC-DLM93: negative control supplemented with DL-Met at 93\% of DLM 100 , DLM $_{93}+$ Bet: $\mathrm{DLM}_{93}$ supplemented with Betaine; $\mathrm{MHA}_{100}$ : methionine hydroxy analogue (MHA) supplementation; MHA negative control supplemented with $93 \%$ of $\mathrm{MHA}, \mathrm{MHA}_{93}+\mathrm{Bet}_{\mathrm{MHA}} \mathrm{MH}_{93}$ supplemented with betaine

${ }^{1}$ Vitamin $A: 10,000 \mathrm{IU}$, vitamin $\mathrm{D}_{3}: 2,500 \mathrm{IU}$, vitamin $\mathrm{E}: 20,000 \mathrm{UI}$, vitamin $\mathrm{K}_{3}: 2,500 \mathrm{mg}$, vitamin $\mathrm{B}_{1}: 1,800 \mathrm{mg}$, vitamin $B_{2}: 6,000 \mathrm{mg}$, vitamin $B_{12}: 16,000 \mathrm{mcg}$, vitamin $B_{6}: 2,600 \mathrm{mg}$, vitamin $B_{3}: 40,000 \mathrm{mg}$, vitamin $B_{5}: 12,000 \mathrm{mg}$, vitamin $B_{7}$ : $65 \mathrm{mg}$, vitamin $\mathrm{B}_{9}: 1,000 \mathrm{mg}$, iron: $50 \mathrm{~g}$, copper: $9 \mathrm{~g}$, zinc: $60 \mathrm{~g}$, manganese: $70 \mathrm{~g}$, iodine: $1 \mathrm{~g}$, selenium: $0.3 \mathrm{~g}$, choline chloride: $0.5 \mathrm{~g}$, salinomycin: $0.55 \mathrm{~g}$, virginiamycin: $0.05 \mathrm{~g}$

\section{Results and Discussion}

The weight gain of broiler chickens from day 1 to day 21 was not affected $(P>0.05)$ by the source of methionine or betaine inclusion. However, according to Dunnett's test, all the treatments, namely DLM $\mathrm{D}_{100}$, $\mathrm{MHA}_{100}, \mathrm{DLM}_{93}+\mathrm{Bet}$, and $\mathrm{MHA}_{93}+$ Bet, produced greater weight gain than the negative controls NC-DLM and NC-MH). Likewise, no interaction effect was detected $(P>0.05)$. Nor was there an effect of either betaine or methionine source on feed intake (Table 3). According to Dunnett's test, broiler chickens receiving the treatments $\mathrm{MHA}_{100}$ and $\mathrm{DLM}_{93}+$ Bet had a smaller FI compared with NC-MHA. Finally, no treatment main effects or interaction effects on FCR were detected $(P>0.05)$. However, the treatments $D^{2} M_{100}, M_{H} A_{100}$, $\mathrm{DLM}_{93}+\mathrm{Bet}$, and $\mathrm{MHA}_{93}+$ Bet had better FCR compared with NC-DLM and NC-MHA. 
Table 3 Performance of broiler chickens receiving DL-Methionine or methionine hydroxy analogue partially replaced by betaine from day 1 to 21

\begin{tabular}{|c|c|c|c|}
\hline Treatment & Weight gain, g/d & Feed intake, g/d & Feed conversion ratio \\
\hline NC-DLM93 & 35.07 & 55.98 & 1.60 \\
\hline $\mathrm{NC}-\mathrm{MHA}_{93}$ & 35.09 & 56.17 & 1.60 \\
\hline $\mathrm{DLM}_{100}$ & $37.49^{\star \#}$ & 54.62 & $1.46^{\star \#}$ \\
\hline $\mathrm{MHA}_{100}$ & $37.24^{\star \#}$ & $55.63^{\#}$ & $1.49^{\star \#}$ \\
\hline $\mathrm{DLM}_{93}+\mathrm{Bet}$ & $37.74^{\star \#}$ & $55.46^{\#}$ & $1.47^{\star \#}$ \\
\hline $\mathrm{MHA}_{93}+\mathrm{Bet}$ & $36.97^{\star \#}$ & 54.64 & $1.48^{\star \#}$ \\
\hline SE & 0.27 & 0.20 & 0.01 \\
\hline \multicolumn{4}{|l|}{$P$-value } \\
\hline Betaine (Bet) & 0.976 & 0.857 & 0.933 \\
\hline Methionine source (Met) & 0.338 & 0.832 & 0.131 \\
\hline Bet $x$ Met & 0.625 & 0.245 & 0.298 \\
\hline
\end{tabular}

MHA: methionine hydroxy analogue, $\mathrm{DLM}_{100}$ : DL-Methionine supplemented, NC-DLM $\mathrm{N}_{93}$ : negative control supplemented with DL-Met at $93 \%$ of $\mathrm{DLM}_{100}$, DLM $\mathrm{DL}_{93}+$ Bet: $\mathrm{DLM}_{93}$ supplemented with Betaine; $\mathrm{MHA}_{100}$ : methionine hydroxy analogue (MHA) supplementation; $\mathrm{NC}-\mathrm{MHA}_{93}$ : negative control supplemented with $93 \%$ of $\mathrm{MHA}, \mathrm{MHA}_{93}+\mathrm{Bet}$ $\mathrm{MHA}_{93}$ supplemented with betaine

Means followed by an * differ from the NC-DLM93 by Dunnett's test at $5 \%$ significance

Means followed by \# differ from the NC-MHA ${ }_{93}$ by Dunnet's $t$ test at $5 \%$ significance

In terms of growth performance from day 22 to day 42 (Table 4), WG, FI and FCR were not affected (P $>0.05$ ) by the treatments, with mean values of $80.2 \mathrm{~g} / \mathrm{d}, 141.93 \mathrm{~g} / \mathrm{d}$, and $1.77 \mathrm{~g} / \mathrm{g}$, respectively.

Table 4 Performance of broiler chickens receiving DL-Methionine or methionine hydroxy analogue partially replaced with betaine from day 22 to 42

\begin{tabular}{lccc}
\hline Treatment & Weight gain & Feed intake & Feed conversion ratio \\
\hline $\mathrm{NC}^{-D L M}{ }_{93}$ & 78.20 & 138.8 & 1.78 \\
$\mathrm{NC}^{-M H A_{93}}$ & 80.29 & 141.7 & 1.77 \\
$\mathrm{DLM}_{100}$ & 79.83 & 140.1 & 1.76 \\
$\mathrm{MHA}_{100}$ & 80.68 & 143.6 & 1.78 \\
$\mathrm{DLM}_{93}+$ Bet & 81.79 & 143.9 & 1.76 \\
$\mathrm{MHA} \mathrm{A}_{93}+$ Bet & 80.42 & 143.5 & 1.78 \\
$\mathrm{SE}$ & 0.35 & 0.6 & 0.01 \\
$P$-value & & & \\
$\quad$ Betaine (Bet) & 0.286 & 0.176 & 0.713 \\
$\quad$ Methionine source (Met) & 0.735 & 0.267 & 0.065 \\
$\quad$ Bet x Met & 0.169 & 0.152 & 0.956
\end{tabular}

MHA: methionine hydroxy analogue, DLM 100 : DL-Methionine supplemented, NC-DLM93: negative control supplemented with DL-Met at $93 \%$ of $\mathrm{DLM}_{100}$, $\mathrm{DLM}_{93}+$ Bet: $\mathrm{DLM}_{93}$ supplemented with Betaine; $\mathrm{MHA}_{100}$ : methionine

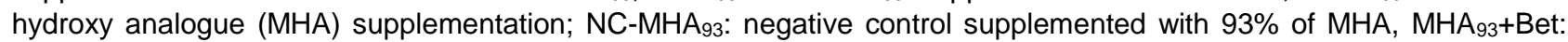
$\mathrm{MHA}_{93}$ supplemented with betaine

When the birds were harvested at day 42 , carcass and wing yields were not affected $(P>0.05)$ by the treatments (Table 5$)$. However, breast yield was influenced by methionine source $(P=0.02)$ with the broiler 
chickens receiving DL-Met having a higher breast yield than those with MHA. When compared with the negative controls, there was no effect of betaine or methionine supplementation. However, the leg yield of birds receiving treatment $\mathrm{DLM}_{100}$ was numerically less than both negative controls, and the leg yield of those treated with $\mathrm{MHA}_{93}+\mathrm{Bet}$ was lower than NC-MHA.

Table 5 Carcass and cuts yield (\%) of broiler chickens receiving DL-Methionine or methionine hydroxy analogue partially replaced with betaine from day 22 to 42

\begin{tabular}{|c|c|c|c|c|}
\hline Item & Carcass & Breast & Legs & Wings \\
\hline NC-DLM 93 & 72.07 & 34.78 & 29.15 & 10.57 \\
\hline NC-MHA $A_{93}$ & 72.37 & 33.54 & 32.13 & 10.36 \\
\hline $\mathrm{DLM}_{100}$ & 74.73 & 35.19 & $29.92^{\star \#}$ & 10.39 \\
\hline $\mathrm{MHA}_{100}$ & 72.36 & 34.78 & 31.30 & 10.21 \\
\hline $\mathrm{DLM}_{93}+\mathrm{Bet}$ & 72.04 & 36.43 & 30.86 & 10.30 \\
\hline $\mathrm{MHA}_{93}+\mathrm{Bet}$ & 74.18 & 32.11 & $29.67^{\#}$ & 9.63 \\
\hline SE & 0.472 & 0.483 & 0.264 & 0.126 \\
\hline \multicolumn{5}{|l|}{ Betaine effect } \\
\hline Without betaine & 73.55 & 34.99 & 30.61 & 10.30 \\
\hline With betaine & 73.11 & 34.27 & 30.27 & 9.97 \\
\hline \multicolumn{5}{|l|}{ Methionine source effect } \\
\hline DL-Methionine & 73.39 & $35.81^{\mathrm{a}}$ & 30.39 & 10.35 \\
\hline Methionine hydroxy analogue & 73.27 & $33.45^{\mathrm{b}}$ & 30.49 & 9.92 \\
\hline \multicolumn{5}{|l|}{$P$-value } \\
\hline Betaine (Bet) & 0.654 & 0.485 & 0.556 & 0.237 \\
\hline Methionine source (Met) & 0.899 & 0.031 & 0.874 & 0.138 \\
\hline Bet $\times$ Met & 0.151 & 0.068 & 0.185 & 0.396 \\
\hline
\end{tabular}

MHA: methionine hydroxy analogue, DLM 100 : DL-Methionine supplemented, NC-DLM93: negative control supplemented with DL-Met at $93 \%$ of $\mathrm{DLM}_{100}$, $\mathrm{DLM}_{93}+$ Bet: $\mathrm{DLM}_{93}$ supplemented with Betaine; $\mathrm{MHA}_{100}$ : methionine hydroxy analogue (MHA) supplementation; NC-MHA $A_{93}$ : negative control supplemented with $93 \%$ of $\mathrm{MHA}, \mathrm{MHA}_{93}+\mathrm{Bet}$ : $\mathrm{MHA}_{93}$ supplemented with betaine

Within an effect, means having similar superscripts were not different with probability $P=0.05$ by Tukey's test

Means followed by an * differ from the NC-DLM 93 by Dunnett's test at $5 \%$ significance

Means followed by \# differ from the NC-MHA $A_{93}$ by Dunnet's t test at $5 \%$ significance

There was no Bet $x$ Met interaction $(P>0.05)$ for body fat content (Table 6$)$. However, the main effect of betaine supplementation indicated that broiler chickens that received betaine had higher body fat content than the birds that were not supplemented with this additive. Dunnett's test indicated that broiler chickens supplemented with betaine had a higher fat content than those in the negative control treatments.

The Bet $\mathrm{x}$ Met interaction affected $(P<0.01)$ for body CP content, such that the birds receiving DLMet $_{93}+$ Bet had higher values than those that were subjected to the other treatments (DL-Met ${ }_{100}, \mathrm{MHA}_{100}$, DLMet ${ }_{93}+\mathrm{Bet}$, and $\left.\mathrm{MHA}_{93}+\mathrm{Bet}\right)$. When the treatments were compared with the negative control diets, the $\mathrm{CP}$ content in the treatment DL-Met ${ }_{100}$ was lower than in the NC-DLM $(P<0.05)$ and the CP content of birds receiving the DL-Met ${ }_{93}+$ Bet treatment was greater than those that received the NC-MHA diet.

The source of methionine had no effect on the growth performance in the two trials, since the diet was supplemented on an equimolar basis, which was consistent with other studies conducted on broiler chickens (Yodseranee \& Bunchasak, 2012; Kluge et al., 2016). However, the efficacy of MHA for replacing DL-Met varied among studies. Payne et al. (2006) reported that the observed efficacy of MHA was $79 \%$ for weight gain and $81 \%$ for FCR on an equimolar basis, which was lower than the $88 \%$ efficacy that they had estimated. Ullrich et al. (2019) also found no differences in the weight gain of broiler chickens fed MHA or DL-methionine from day 1 to day 34 .

Carcass yield was not impaired by the negative control diets, which can be attributed to the low level of methionine restriction. Nor was it influenced by methionine source or betaine supplementation. The higher 
breast yield in broilers receiving DL-Met than those that received MHA was consistent with the results of Esteve-Garcia and Llauradó (1997), who reported the relative efficacy of DL-methionine hydroxy analogue free acid relative to DL-methionine was $51 \%$ and suggested that breast yield might be a more sensitive parameter for testing the efficacy of various methionine sources than growth or feed conversion efficiency. Chen et al. (2018) evaluated a basal diet with DL-Met according to broiler chicken requirements plus betaine, and obtained a higher breast yield with the inclusion of $1000 \mathrm{mg} \mathrm{Bet} / \mathrm{kg}$ compared with the basal diet, with no differences at the inclusion levels of 250 and $500 \mathrm{mg} \mathrm{Bet} / \mathrm{kg}$.

Table 6 Body composition of broiler chickens receiving DL-Methionine or methionine hydroxy partially replaced with betaine from day 22 to 42

\begin{tabular}{lcc}
\hline Treatment & Fat, \% & Crude Protein, \% \\
\hline NC-DLM93 & 12.83 & 21.44 \\
NC-MHA93 & 11.45 & 21.21 \\
DLM100 & 11.13 & $20.34^{\star \mathrm{b}}$ \\
MHA100 & 11.93 & $20.76^{\mathrm{b}}$ \\
DLM93+Bet & $13.84^{\#}$ & $22.48^{\# \mathrm{a}}$ \\
MHA93+Bet & $13.72^{\#}$ & $20.82^{\mathrm{b}}$ \\
SE & 0.246 & 0.167 \\
Betaine effect & & \\
$\quad$ Without betaine & $11.53^{\mathrm{b}}$ & 20.55 \\
$\quad 13.78^{\mathrm{a}}$ & 21.65 \\
With betaine & & \\
Methionine source effect & 12.49 & 21.40 \\
$\quad$ DL-Methionine & 12.83 & 20.79 \\
$\quad$ Methionine hydroxy analogue & & $<0.001$ \\
P-value & $<0.001$ & 0.008 \\
$\quad$ Betaine (Bet) & 0.404 & $<0.001$ \\
$\quad$ Methionine source (Met) & 0.270 & \\
$\quad$ Bet x Met & &
\end{tabular}

MHA: methionine hydroxy analogue, DLM 100 : DL-Methionine supplemented, NC-DLM93: negative control supplemented with DL-Met at $93 \%$ of $\mathrm{DLM}_{100}$, DLM ${ }_{93}+$ Bet: DLM ${ }_{93}$ supplemented with Betaine; $\mathrm{MHA}_{100}$ : Methionine hydroxy analogue (MHA) supplementation; $\mathrm{NC}-\mathrm{MHA}_{93}$ : negative control supplemented with $93 \%$ of $\mathrm{MHA}, \mathrm{MHA}_{93}+\mathrm{Bet} \mathrm{MHA} 93$ supplemented with betaine

Within an effect, means with similar superscripts were not different with probability $P=0.05$ by Tukey's test

Means followed by an asterisk * differ from the NC-DLM ${ }_{93}$ by Dunnett's test at $5 \%$ significance

Means followed by hashtag \# differ from the NC-MHA $\mathrm{A}_{93}$ by Dunnet's t test at $5 \%$ significance

The increase in body fat content with betaine supplementation was an unexpected result, since betaine may increase fat metabolism and reduce the availability of long chain fatty acids for storage in adipose tissue (He et al., 2015; Chen et al., 2018). However, Met-replacing and fat-distribution effects of betaine differ in the literature (Yang et al., 2017). Zhan et al. (2006) reported a higher plasma concentration of free fatty acids and a trend toward higher fat deposition in the breast of broilers fed a methionine-deficient diet supplemented with betaine. Garcia Neto et al. (2000) also found higher fat deposition in the carcass of broilers fed betaine instead of methionine as the main source of methyl groups. One possible explanation for these differing results was documented in trials with pigs (Suster et al., 2004; Dunshea et al., 2009), where a reduction in the total amount of body fat was observed as well as changes the distribution of adipose tissues in the body. However, in the present study only total body fat percentage was evaluated.

Betaine favours skeletal muscle growth by increasing the expression of myogenic regulatory factors such as myogenic determination factor 1 and myogenin, thereby enhancing metabolic pathways associated with protein synthesis (Chen et al., 2018). However, the reasons for the higher amounts of fat in MHA treatments and higher body protein in broilers fed $\mathrm{DLM}_{93}+$ Bet are not completely understood. Sun et al. (2008) evaluated the partial replacement of DL-Met at $75 \%$ of broiler chicken requirements plus $500 \mathrm{mg}$ 
Bet $/ \mathrm{kg}$ and recorded a higher fat and protein content in the breast of supplemented broiler chickens at day 42 compared with the control diet. They also found elevated serum levels of growth hormone and insulin-like growth factor-1 (IGF-1) and reported that these metabolites were positively related to feed efficiency, plus increased protein content at that level of betaine supplementation.

\section{Conclusion}

The source of methionine did not influence the growth from day 1 to 21 or from day 22 to 42 or carcass yield at day 42 of broiler chickens. Betaine could partially replace methionine without altering the growth performance of broiler chickens. The partial replacement of DL-Met with betaine increased body crude protein. However, its use increased body fat content, regardless of methionine source.

\section{Authors' contributions}

LS, CS and JB collected the data. BSV and ASA, conducted the statistical analyses, and collaborated in interpretation of the results. LS and LDC wrote the initial draft of this manuscript and finalized the manuscript. RVN, SET and PSC developed the original hypothesis, designed the experiments, and collaborated in interpreting the results. The authors have read and approved the finalized manuscript.

\section{Conflict of interest declaration}

The authors declare there is no conflict of interest.

\section{References}

AOAC, 2002. Official methods of analysis of AOAC International. 15th ed. Association of Official Analytical Chemists, Arlington, VA, USA.

Chen R., Zhuang, S., Chen, Y.P., Cheng, Y.F., Wen, C. \& Zhou, Y.M., 2018. Betaine improves the growth performance and muscle growth of partridge shank broiler chickens via altering myogenic gene expression and insulin-like growth factor-1 signalling pathway. Poult. Sci. 97(12), 4297-4305. doi: 10.3382/psfrom/pey303

Craig, S.A.S., 2004. Betaine in human nutrition. Am. J. Clin. Nutr. 80, 539-549. doi: 10.1093/ajcn/80.3.539

Dunshea, F.R., Cadogan, D.J. \& Partridge, G.G., 2009. Dietary betaine and ractopamine combine to increase lean tissue deposition in finisher pigs, particularly gilts. Anim. Prod. Sci. 49, 65-70. doi: 10.1071/EA08014

Esteve-Garcia, E. \& Llauradó, L., 1997. Performance, breast meat yield and abdominal fat deposition of male broiler chickens fed diets supplemented with DL-methionine or DL-methionine hydroxy analogue free acid. Br. Poult. Sci. 38, 397-404. doi: 10.1080/00071669708418009

Fu, Q., Leng, Z.X., Ding, L.R., Wang, T., Wen, C. \& Zhou, Y.M., 2016. Complete replacement of supplemental dlmethionine by betaine affects meat quality and amino acid contents in broilers. Anim. Feed Sci. Tech. 212, 63-69. doi: 10.1016/j.anifeedsci.2015.12.004

Garcia Neto, M., Pesti, G.M. \& Bakalli, R.I., 2000. Influence of dietary protein level on the broiler chicken's response to methionine and betaine supplements. Poult. Sci. 79, 1478-1484. doi: 10.1093/ps/79.10.1478

He, S., Zhao, S., Dai, S., Liu, D. \& Bokhari, S.G., 2015. Effects of dietary betaine on growth performance, fat deposition and serum lipids in broilers subjected to chronic heat stress: Betaine effects on heat-stressed broilers. Anim. Sci. J. 86, 897-903. doi: 10.1111/asj.12372

Kluge, H., Gessner, D.K., Herzog, E. \& Eder, K., 2016. Efficacy of DL-methionine hydroxy analogue-free acid in comparison to DL-methionine in growing male white Pekin ducks. Poult. Sci. 95, 590-594. doi: 10.3382/ps/pev355

Leeson, S. \& Summers, J., 2008. Feeding Programs for broiler chickens. In: S. Lesson \& S.D. Summers (eds). Commercial Poultry Nutrition. University Books. Guelph.

Leng, Z., Fu, Q., Yang, X., Ding, L., Wen, C. \& Zhou, Y., 2016. Increased fatty acid $\beta$-oxidation as a possible mechanism for fat-reducing effect of betaine in broilers: Betaine and lipid metabolism in broilers. Anim. Sci. J. 87, 1005-1010. doi: $10.1111 /$ asj. 12524

Lobanov, A.V., Turanov, A.A., Hatfield, D.L. \& Gladyshev, V.N., 2010. Dual functions of codons in the genetic code. Crit. Rev. Biochem. Mol. Biol. 45, 257-265. doi: 10.3109/10409231003786094

Nutautaitè, M., Alijošius, S., Bliznikas, S., Šašytè, V., Vilienè, v., Pockevičius, A. \& Racevičiūtè-Stupelienè, A., 2020. Effect of betaine, a methyl group donor, on broiler chicken growth performance, breast muscle quality characteristics, oxidative status and amino acid content. Ital. J. Anim. Sci. 19, 621-629. doi: $10.1080 / 1828051 X .2020 .1773949$

Payne, R.L., Lemme, A., Seko, H., Hashimoto, Y., Fujisaki, H., Koreleski, J., Swiatkiewicz, S., Szczurek, W. \& Rostagno, H., 2006. Bioavailability of methionine hydroxy analog-free acid relative to DL-methionine in broilers. Anim. Sci. J. 77, 427-439. doi: 10.1111/j.1740-0929.2006.00369.x

Rama Rao, S.V., Raju, M.V.L.N., Panda, A.K., Saharia, P. \& Sunder, G.S., 2011. Effect of supplementing betaine on performance, carcass traits and immune responses in broiler chicken fed diets containing different concentrations of methionine. Asian-Australas. J. Anim. Sci. 24, 662- 669. doi: 10.5713/ajas.2011.10286

Rehman, A.U., Arif, M., Husnain, M.M., Alagawany, M., Abd El-Hack, M.E., Taha, A.E., Elnesr, S.S., Abdel-Latif, M.A., Othman, S.I. \& Allam, A.A., 2019. Growth performance of broilers as influenced by different levels and sources of methionine plus cysteine. Animals, 9. doi: 10.3390/ani9121056 
Rostagno, S.H., Albino, L.F.T., Donzele, J.L., Gomes, P.C., Oliveira R.F., Lopes D.C., Ferreira, A.S., Barreto, S. L.T. \& Euclides, R.F., 2011. Brazilian tables for poultry and swine: feed composition and nutritional requirements. Third ed. UFV, Viçosa.

Sakomura, N.K. \& Rostagno, H.S. 2016. Research methods in monogastric nutrition. Second ed. Funep, Jaboticabal.

Sauer, N., Emrich, K., Piepho, H.P., Lemme, A., Redshaw, M.S. \& Mosenthin, R., 2008. Meta-analysis of the relative efficiency of methionine-hydroxy-analogue-free-acid compared with DL-Methionine in broilers using nonlinear mixed models. Poult. Sci. 87, 2023-2031. doi: 10.3382/ps.2007-00514

Scanes, C., 2015. Protein metabolism. In: C.G. Scanes (ed). Sturkey's avian physiology. Academic Press. San Diego.

Shakeri, M., Cottrell, J.J., Wilkinson, S., Le, H.H., Suleria, H.A.R., Warner, R.D. \& Dunshea, F.R., 2019. Growth performance and characterization of meat quality of broiler chickens supplemented with betaine and antioxidants under cyclic heat stress. Antioxidants 8, doi: 10.3390/antiox8090336

Sun, H., Yang, W.R., Yang, Z.B., Wang, Y., Jiang, S.Z. \& Zhang, G.G., 2008. Effects of betaine supplementation to methionine deficient diet on growth performance and carcass characteristics of broilers. Am. J. Anim. Vet. Sci. 3, 78-84. doi: 10.3844/ajavsp.2008.78.84

Suster, D., Leury, B.J., King, R.H., Mottram, M. \& Dunshea, F.R., 2004. Interrelationships between porcine somatotropin (pST), betaine, and energy level on body composition and tissue distribution of finisher boars. Aust. J. Agric. Res. 55, 983-990. doi: 10.1071/AR04029

Ullrich, C., Langeheine, M., Brehm, R, Taube, V., Galera, M.R., Rohn, K., Popp, J. \& Visscher, C., 2019. Influence of different methionine sources on performance and slaughter characteristics of broilers. Animals 9, 984. doi: 10.3390/ani9110984

Visentini P., Lopes, J., Toledo, G.S. \& Costa, P.T., 2005. Levels of substitution of DI-methionine by methionine hidroxy analogue in basis equimolar in broilers diets. Cienc. Rural 35, 1400-1405. doi: 10.1590/S010384782005000600027

Yang, Z., Wang, Z.Y., Yang, H.M., Xu, L. \& Gong, D.Q., 2017. Effects of dietary methionine and betaine on slaughter performance, biochemical and enzymatic parameters in goose liver and hepatic composition. Anim. Feed Sci. Technol. 228, 48-58. doi: 10.1016/j.anifeedsci.2017.04.003

Yodseranee, R. \& Bunchasak, C., 2012. Effects of dietary methionine source on productive performance, blood chemical, and hematological profiles in broiler chickens under tropical conditions. Trop. Anim. Health Prod. 44, 1957-1963. doi: 10.1007/s11250-012-0164-7

Zhan, X.A., Li, J.X., Xu, Z.R. \& Zhao, R.Q., 2006. Effects of methionine and betaine supplementation on growth performance, carcase composition and metabolism of lipids in male broilers. Brit. Poult. Sci. 47, 576-580. doi: $10.1080 / 00071660600963438$ 